\title{
The Impact of the Federal Rules of Civil Procedure on Bankruptcy
}

\section{Leon R. Yankwich*}

The object of this article is to consider some of the uses to which the procedural scheme devised by the Federal Rules of Civil Procedure has been put in bankruptcy. Procedure by rule is not novel in the field of bankruptcy. Section 30 of the Bankruptcy Act of 1898 contained the provision which went into effect on July $1,1898,{ }^{1}$ and which is carried over into the present act, $^{2}$ giving the Supreme Court of the United States the power to prescribe the necessary rules, forms and orders as to procedure under the act.

In obedience to this mandate that Court on November 28, 1898, promulgated the General Orders in bankruptcy which, with subsequent modifications, have, in reality, constituted a code of procedure in bankruptcy.

General Order 27, as then promulgated, made applicable to bankruptcy practice the rules of equity practice established by the Supreme Court "as nearly as may be."

A like provision enjoined the bankruptcy courts to follow the practice and procedure in cases at law. Equity procedure in the federal courts has been governed by court rules since 1822 . Procedure on the law side, prior to the adoption of the federal rules of civil procedure, has conformed, even since the beginning of our judicial system, to local practice. ${ }^{3}$ The various statutory provisions culminated in the Conformity Act of $1872 . .^{4}$ The Federal Rules of Civil Procedure became effective on September 16, 1938. The rules provide: 5

These rules do not apply ... to proceedings in bankruptcy ... except in so far as they may be made applicable thereto by rules promulgated by the Supreme Court of the Umited States.

Following the adoption of the rules, the Supreme Court amended Orders 36 and 37, whicl amendments became effective February 13, 1939. Order 36 relates to appeal, which does not concern us in this discussion. The amended Order 37 reads into bankruptcy procedure the Federal Rules of Civil Procedure, with modifications. It states: ${ }^{6}$

* Chief United States District Judge, Southern District of California.

130 Stat. 554 (1898).

2 Bankruptcy Act of 1938, § 30, 11 U.S.C.A. \& 53. The Bankruptcy Act of 1938 is found in 52 STAT. $840-940$ (1938), 11 U.S.C. $\S 1$ ff. (1952).

31 Stat. 275 (1792); 4 Stat. 278 (1828).

428 U.S.C.A. old § 724, now superseded by the Federal Rules of Civil Procedure.

5 FED. R. Crv. P. 81 (a) (1).

6 Generat Orders in Bankruptcy, Order 37. 
In proceedings under the Act the Rules of Civil Procedure for the District Courts of the United States shall, in so far as they are not inconsistent with the Act or with these general orders, be followed as nearly as may be. But the court may shorten the hmitations of time prescribed so as to expedite hearings, and may otherwise modify the rules for the preparation or hearing of any particular proceeding.

\section{PROCEDURE BY RULE}

Although as appears from what has gone before, procedure by rule has a long history in bankruptcy, it may not be amiss to point out some of its advantages. For, despite the fact that rules have governed civil procedure in the federal courts since 1938, voices are still heard in opposition to the philosophy they embody, especially insofar as they simplify the requirements as to the statement of a claim and minimize, through discovery, the element of surprise in the trial of a civil action. ${ }^{7}$

The call for procedure by rule of court springs, primarily, from a desire and need for elasticity and adaptability. Rigid procedural schemes established by legislative bodies lack these qualities. As one writer has put it: ${ }^{8}$

Rules of procedure laid down by legislative mandate do not grow spontaneously out of the exact requirements of actual practice, and they fail to show that delicate adaptability to circumstances which distinguishes a professional techmique. They embody legislative theory, not judicial experience, and often tend to destroy by their clumsy abstractness the very purposes which they are created to serve. The subtle appreciation of the conditions of litigation, which can only come to those who spend their lives in the active administration of justice, is not possible among the niembers of a popular assembly who meet to make the laws.

Society is becoming more and more complex. So are the relationships which are the source of legal controveries. Legal procedure should keep step with social development and be able to adapt itself to new conditions. The regulation of procedure by rule of court enables us to avoid, easily and quickly, glaring injustices which may arise under general rules, and to achieve judicious simplification when and where necessary. Above all, it makes it possible to adapt procedure to the rapid changes of life about us.

Governments, through legislative bodies, have little imterest in our procedural scheme. There are, of course, many things procedural which involve matters of governmental policy. But most of them either do not

${ }^{7}$ See Report of Comanittee on Federal Practice and Procedure, Oregon State Bar, 1950 Annual Committee Reports 58-59; McCaskill, The Modern Philosophy of Pleading: A Dialogue Outside the Shades, 38 A.B.A.J. 123 (1952); Hawkins, Discovery and Rule 34: What's So Wrong About Surprise?, 39 A.B.A.J. 1075 (1953).

8 Sutherland, LI A.B.A. REP. 281 (1926). 
relate to questions of policy or merely serve to give effect to them. The matter can be left safely in the hands of the courts. The enhanced freedom of the courts resulting from the removal of legislative restraint and the restoration to them of the rule-making power, enables them to perform their function more adequately. And, ultimately, society benefits.

Pound has written: ${ }^{8}$

Apprentice-trained, rule-of-the-thumb-trained lawyers have been unable to think of administration of justice without a hypertrophy of procedure. But we cannot go on in the urban, industrial America of today under the heavy weight of procedural detail with which our courts are struggling. If we demand that our courts do things, we inust give them power to do thingswe must set them free to do things. We must hold them to the substantive law, indeed. But we must not make the substantive law nugatory by loading the courts with procedural requirements. We must cease to prescribe the details of procedure by legislation. None of you would think of urging a code of substantive law. But every reason you would bring forward against such a code is strong tenfold against codes of procedure and detailed practice acts.

Procedure by rule in bankruptcy has an added significance, because of the importance of achieving umformity in administration. It makes it possible to develop a unitary system of procedure aiming to attain in a uniform manner the primiary object of the bankruptcy act, which, to paraphrase an old decision, is to release the bankrupt from the obligation to pay the debts of his creditors and "to secure a just distribution" 10 of the bankrupt's property among them.

III

\section{THE BROAD SCOPE OF BANKRUPTCY POWERS}

The importance of uniform rules of procedure in achieving this result becomes evident, if we consider the broad scope of the general jurisdiction of the bankruptcy court. The Umited States Court of Appeals for the Nimth Circuit very recently has stated it in this manner: ${ }^{11}$

The Bankruptcy Court's jurisdiction generally is divided into three classes:

(1) proceedings in bankruptcy; (2) controversies arising in proceedings in bankruptcy; and (3) controversies at law and in equity, as distinguished from proceedings under the Bankruptcy Act in suits between receivers and

${ }^{9}$ Pound, The Rule-Making Power of the Courts, 12 A.B.A.J. 599, 603 (1926).

10 Wilson v. City Bank, 17 Wall. 473, 480 (U.S. 1873). "The fundamental principle of the act is a real and effectual equality in the distribution of the bankrupt estate. Lowell, Bankr. p. 43. In the disposition of property among creditors, equality is equity. Bank v. Sherman, 101 U.S. 403, 406, 25 L.Ed. 866." In re Fixen, 102 Fed. 295, 297 (9th Cir. 1900).

11 Evarts v. Eloy Gin Corp., 204 F.2d 712, 715-716 (9th Cir. 1953); see Bankruptcy Act § 2 (a), 11 U.S.C.A. \$11(a); Bankruptcy Act $\$ 2$ (a) (7), 11 U.S.C.A. §11(a) (7); Bankruptcy Act $\$ 23(\mathrm{a})$ (1938), 11 U.S.C.A. $\$ 46(\mathrm{a})$. 
trustees as such and adverse claimants, concerning property acquired or claimed by the receiver or trustees.

"Proceedings in bankruptcy" include, generally, all matters of administration such as the allowance and rejection of claims, the reduction of the properties to money and its distribution, the determination of preferences and priorities for allowance in payment and the supervision and control of the trustees. In these matters the jurisdiction of the bankruptcy court is both summary and exclusive. "Controversies arising in proceedings in bankruptcy" cover all matters which concern the right and title to the bankrupt's estate. They include disputes as to whether certain property is a part of the estate. And only when the property is, actually or constructively, in the possession of the bankruptcy court can that court determine the matter summarily..$^{13}$ And if the property came into the hands of a person prior to bankruptcy and that person asserts a real and not merely a colorable claim, a plenary action must be resorted to in order to determine the title of the estate in it, ${ }^{14}$ unless the claimant of the property consents to a summary adjudication. $^{15}$

In 1952, Congress inserted the following amendment to Section 2(7) of the Act: ${ }^{18}$

[A]nd where in a controversy arising in a proceeding under this title an adverse party does not interpose objection to the summary jurisdiction of the court of bankruptcy, by answer or motion filed before the expiration of the time prescribed by law or rule of court or fixed or extended by order of court for the filing of an answer to the petition, motion or other pleading to which he is adverse, he shall be deemed to have consented to such jurisdiction.

The amendment, while not enlarging the jurisdiction of the court, may, in effect, validate summary action if the interested party fails to object to such action. ${ }^{17}$ The impact of the rules on bankruptcy must be considered against this background. When this is done it will become evident that the rules have given to the bankruptcy court new tools for achieving the release of the debtor from his debts and the equitable distribution of his property among his creditors.

128 CortTER, BANKRUPtCI 119-120 (14th ed. 1941).

13 Id. at 120-121. See the writer's opinion In re Club New Yorker, 14 F.Supp. 694 (S.D. Cal. 1936), and In re Rand Mining Co., 11 F.Supp. 724 (S.D. Cal. 1947).

142 Colimer, BANkruptcx 447-506 (14th ed. 1941); Chatz v. Freeman, 204 F.2d 764, 767 (7th Cir. 1953); and see In re Patrick, 194 F.2d 750, 752 (7th Cir. 1952); B. F. Avery \& Sons Co. v. Davis, 192 F.2d 255 (5th Cir. 1951).

15 Cline v. Kaplan, 323 U.S. 97, 98-100 (1944).

1611 U.S.C.A. \$11(a) (7).

17 Sloan, Procedural Effect of the 1952 Amendment to Section 2(a)(7) of the Bankruptcy Act, 28 J.N.A. REF. BANKR. 32 (1954). 
Even before the enactment of the Federal Rules of Civil Procedure, the rules of practice and procedure promulgated in the General Orders were given the effect of law. ${ }^{18}$ And where a limitation of time is imposed it will be strictly followed, except where strict enforcement would prevent a hearing on the merits and result in unnecessary hardship..$^{10}$

The Federal Rules of Civil Procedure, through their liberality, save many steps in procedure which would be lost through strict enforcement of the old rules. The point may be illustrated from the decisions of our own Court of Appeals. Before the enactment of the new rules, that court held that a minute order confirming the report of a special master which recommended the refusal of an adjudication and dismissing an involuntary petition in bankruptcy was a final, appealable order. And, that a more formal order signed by the court entered subsequently could not extend the finality of the prior minute order.$^{20} \mathrm{~A}$ similar problem came before the court after the rules went into effect. It arose from the same court and involved a minute order of the same type which the court had considered in the previous case. However, because Rule 58 of the Federal Rules of Civil Procedure required the entry of the judgment by the clerk, the date of that entry was considered the starting point for the appeal period and not the court's prior minute order. The court, in distinguishing the prior decision, said: ${ }^{21}$

This predated minute entry did not constitute the entry of the order here appealed from (1) because it was not made in the docket and (2) because the order appealed from was entered long before the minute entry was made. The order having been entered on May 5, 1942, this appeal, taken on June 4,1942, was in time. Our decision in Mutual Building \& Loan Ass'n. v. King, 9 Cir., 83 F.2d 798, cited by appellees, was prior to the adoption of the Federal Rules of Civil Procedure.

And where a proceeding under Section 75 of the Bankruptcy Act ${ }^{22}$ was dismissed (on the ground that the petitioner was not a farmer) by an order entered which read, "Motion to dismiss proceedings granted," the court invoked the provision of the rules requiring findings of fact ${ }^{23}$ and held that the issue tendered by the petitioner-whether or not the petitioner was a

18 Conboy v. First National Bank, 203 U.S. 141 (1906).

10 Kelly v. United States, 300 U.S. 50 (1937). And see the writer's opinion In re C. \& P. Co., 63 F.Supp. 400 (S.D. Calif. 1945) ; See also Oppenheimer v. Oldham, 178 F.2d 386 (5th Cir. 1949); Leonard v. Bennett, 116 F.2d 129 (9th Cir. 1940).

${ }^{20}$ Mutual Bldg. \& Loan Ass'n v. King, 83 F.2d 798 (9th Cir. 1936).

21 Rosenberg v. Heffron, 131 F.2d 80, 82 (9th Cir. 1942).

2211 U.S.C.A. \$ 203.

23 FED. R. CIV. P. 52 (a). 
farmer-was an issue of fact, which required findings. The absence of such findings, the court ruled, invahidated the order, which was reversed, with direction to the court to find the facts and state separately its conclusion of law on the issue. ${ }^{24}$ The position of the findings of the referee on review or on appeal has not been changed materially by the application of the rules. Before the rules were made applicable to bankruptcy, General Order 47 read:

The reports of referees in all proceedings under the Act ... shall be deemed presumptively correct, but shall be subject to review by the court, and the court may adopt the same, or may modify or reject the same in whole or in part when the court in the exercise of its judgment is fully satisfied that error has been committed ....

The word "reports" was held broad enough to cover the decisions and findings of the referee..$^{25}$ The effect to be given by the courts to the referee's findings was stated by the United States Court of Appeals for the Eighth Circuit in this manner: ${ }^{26}$

The determination of a referee in bankruptcy of issues of fact, based upon evidence of witnesses appearing im person before him, where such determination must rest upon the credibility of the witnesses and the weight of their evidence, should ordmarily be accepted upon review, except in those cases where it is obvious that the referee has made a mistake.

After the enactment of the Federal Rules of Civil Procedure, the wording of General Order 47 was changed to read as follows:

Unless otherwise directed in the order of reference the report of a referee or of a special master shall set forth his findings of fact and conclusions of law, and the judge shall accept his findings of fact unless clearly erroneous. The judge after hearmg may adopt the report or may modify it or may reject it in whole or in part or may receive further evidence or may recommit it with instructions.

The change read into the order the substance of the provisions of the rules under which findings are not overturned unless they are "clearly erroneous." 27

The amended order has made findings by the referee obligatory in instances where they would not have been required before. ${ }^{28}$ However, in the

24 Perry v. Baumann, 122 F.2d 409 (9th Cir. 1941).

25 Small v. Kiel, 101 F.2d 444, 446 (8th Cir. 1939); In re Byrd Coal Co., 83 F.2d 190, 192 (2d Cir. 1936).

${ }^{26}$ Rasmussen v. Gresly, 77 F.2d 252, 254 (8th Cir. 1935). This is also the view of the United States Court of Appeals for the Ninth Circuit: Grande v. Arizona Wax Paper Co., 90 F.2d 801, 807 (9th Cir. 1937) ; Ott v. Thurston, 76 F.2d 368, 369-370 (9th Cir. 1935).

27 FED. R. CIv. P. 52(a). See Yankwich, Findings in the Light of Recent Amendments to the Federal Rules of Civil Procedure, 8 F.R.D. 271 (1948).

28 Rosenberg v. Heffron, 131 F.2d 80 (9th Cir. 1942). 
main, the circumstances under which the court will sustain a referee's findings are substantially the same as under the order as it stood before. To use the expression of our own Court of Appeals, the findings will not be disturbed "except for manifest error" where they "are concurred in by the referee and the district judge." ${ }^{29}$ However, if there is no substantial evidence to support it, a finding will not be sustained. In a case which arose in the Third Circuit, the bankrupt had been denied discharge upon the grounds that, as president of the corporation, he had obtained a loan for it by false representation and that he was a large stockholder in it. On appeal, the court found that there was no evidence to sustain the finding, saying: ${ }^{30}$

The record, however, utterly fails to support the Referee's determination that the bankrupt was "a large stockholder" in the corporation. Indeed, it is bare of any proof as to the extent of the stock holdings of the bankrupt; there is only testimony to the effect that he was a stockholder-nothing more, nothing less. Moreover, there is nothing in the Referee's statement of facts or in his conclusion of law which gives any light as to his reason for finding that the bankrupt was "a large stockholder." Apparently the Referee based his finding on "speculation" or "intuition."

On that score, we have on previous occasions held that "A finding of fact inust have inore substantial foundation than an intuition ..." and that while the trier of the facts "... has the primary function of finding the facts ... weighing the evidence, and choosing from among conflicting factual inferences and conclusions those which it considers most reasonable" it is well-settled that speculation cannot be substituted for proof and "the requirement is for probative facts capable or supporting, with reason, the conclusions expressed in the verdict." In re Tueders' Estate, 3 Cir., 1947, 164 F.2d 128, 133; Sharon Herald Co. v. Granger, 3 Cir., 1952, 195 F.2d 890,895 .

And where under state law an oral chattel mortgage was valid if registered on the title certificate of the motor vehicle, the refusal of the referee to recognize it was set aside, the court saying: ${ }^{31}$

We think an oral mortgage once registered according to law gives notice of a valid hen to creditors. What possible difference can it make to creditors and third-parties whether the lien which appears on the title certificate is evidenced by an oral mortgage or a written nortgage? Certainly, the lien registered on the title certificate gives the same notice, be the underlying

29 Grande v. Arizona Wax Paper Co., 90 F.2d 801, 807 (9th Cir. 1937). See Larsen v. Marzall, 195 F.2d 200, 202 (D.C.Cir. 1952); Wynne v. Boone, 191 F.2d 220, 222-223 (D.C. Cir. 1951); In re Berberich, 190 F.2d 53 (7th Cir. 1951); Simon v. Schactzel, 189 F.2d 597 (10th Cir. 1951); Cunningham v. Elco Distributors, 189 F.2d 87, 88-89 (6th Cir. 1951); Gordon v. Woods, 189 F.2d 76, 79 (1st Cir. 1951) ; Boyce v. Chemical Plastics, 175 F.2d 839, 841 (8th Cir. 1949); In re Euclid Doan Co., 104 F.2d 712, 715 (6th Cir. 1939).

80 In re Leichter, 197 F.2d 955, 957 (3d Cir. 1952); see Ward v. Deavers, 203 F.2d 72, 76 (D.C. Cir. 1953).

31 Staunton Industrial Loan Corp. v. Wilson, 190 F.2d 706, 709-710 (4th Cir. 1951). 
mortgage oral or written. The objection that an oral mortgage is not enforceable against creditors since creditors cannot know of the existence of an oral mortgage is without force here. No creditor can complain that he has been misled, for the lien is registered for all to see. This Court does not believe that technicalities without substance should control.

In Virginia today, a man would not buy an automobile on the strength of possession, for the sole evidence of ownership of a motor vehicle is the registered title. See Thomas v. Mullins, 153 Va. 383, 149 S.E. 494. So, too, a creditor must not be misled by possession, but must look to the title certificate, and when a lien is registered thereon, notice is given, be the mortgage oral or written.

In these cases the court gives effect to the ruling of the Supreme Court which in interpreting the words "clearly erroneous" in the Federal Rules of Civil Procedure ${ }^{32}$ holds that a finding is "clearly erroneous" when

although there is evidence to support it, the reviewing court on the entire evidence is left with the definite and firm conviction that a mistake has been committed. ${ }^{33}$

IV

\section{THE OUTSTANDING FEATURES OF THE RULES}

It is not the object of this study to review or even list the cases in which the various rules have been applied to bankruptcy. The aim is, as the title implies, to indicate the impact of the rules upon bankruptcy practice. Some of the results have already been referred to. ${ }^{34}$

In discussing others, we shall limit ourselves to those rules that represent outstanding characteristics of the procedural scheme embodied in the rules. In the main, the following represent the means by which the makers of the rules aim "to secure the just, speedy, and inexpensive determination of every action." 35

(a) The fusion of law and equity resulting in the abolition of the rigorous distinction between the two..$^{36}$

(b) Simplicity of pleadings. ${ }^{37}$

(c) Broad rules of joinder of parties and claims. ${ }^{38}$

32 FED. R. Crv. P. 52 (a).

33 United States v. Gypsun Co., 333 U.S. 364, 395 (1948). And see United States v. Oregon Med. Soc., 343 U.S. 326, 329 (1952).

34 See pt. III, supra. A seriatim list of cases in which the rules have been applied is found in Nadler, The Federal Rules of Civil Procedure Applied to Bankruptcy, 27 JN.A. REF. BankR. 49 , n. 26 (1953).

35 FED. R. Crv. P. 1.

30 FED. R. Crv. P. 2.

37 FED. R. Crv. P. 8.

38 FED. R. Crv. P. 18, 19, 20, 21. 
(d) Comprehensive provisions for interpleader, class actions and intervention. ${ }^{89}$ like. ${ }^{40}$

(e) Discovery through depositions, requests for admissions, and the

(f) Pre-trial procedure to simplify and clarify the issues. ${ }^{41}$

(g) Summary judgments seeking to eliminate unreal claims and defenses. ${ }^{42}$

(h) Declaratory judgments by which rights may be adjudicated before actual injury. ${ }^{43}$

(i) A liberal policy in receiving evidence which favors the statute or rule favoring the reception of evidence. ${ }^{44}$

From the time of the adoption of the rules and their application to bankruptcy, the courts have adopted a liberal and generous attitude towards those who sought the aid of the rules in bankruptcy. Following are some instances of the use of the particular rules just referred to.

\section{A. Law and Equity}

A trustee in bankruptcy brought a plenary action in the federal court to recover some pig iron alleged to be a part of the assets of the estate. The complaint stated that the property came into the possession of the defendant under a fraudulent transfer from the bankrupt. The complaint failed to allege specifically that there had been a demand for the property on the part of the trustee and the refusal on the part of the claimant. A motion to dismiss upon the ground that the complaint failed to state a claim upon which relief could be granted ${ }^{45}$ was denied, the court saying: ${ }^{48}$

\footnotetext{
39 FEd. R. CTv. P. 22, 23, 24.

40 FED. R. Crv. P. 26-37.

41 FEd. R. Civ. P. 16.

42 FED. R. CIV. P. 56.

43 FED. R. CIV. P. 57.

44 FED. R. CIv. P. 43.

45 FED. R. CIV. P. 12(b).
}

43 Commonwealth Trust Co. v. Reconstruction F. Corp., 28 F.Supp. 586, 588 (W.D.Pa. 1939). This early decision accords with later cases which seek to determine the sufficiency of a complaint by what the facts show and not by the manner in which the pleader has designated his complaint, or the rehief he has asked. Courts will grant the relief to which the plaintiff is entitled under the facts.

So the fact that a money judgment was used by the trustee for conversion of property, Bankruptcy Act $\$ 60($ b) , 11 U.S.C.A. $\$ 96(b)$, did not prevent the court from granting the return of the property where it appeared that it had not been technically "converted." Perkins v. Remillard, 84 F.Supp. 224, 228 (D.Mass. 1949). And see Falk v. Levine, 60 F.Supp. 660, 663 (D. Mass. 1945) in which it is stated that ". . the test of the complaint upon a motion to dismiss lies in the claim not in the demand." (Emphasis added). Where goods could not be returned, the intervenor was entitled to judgment for their value. Craig v. Smith, 192 F.2d 427 (5th Cir. 1951).

A dismissal will not be upheld merely because the complaint did not ask the proper relief. As said by the Court of Appeals for the District of Columbia: ". . . a complaint is sufficient 
As to the other grounds of dismissal, i.e., that the complaint fails to state a claim on which relief can be granted, it is without merit. As we have already stated, the complaint states the defendant is in possession of pig iron to which the plaintiff is entitled. It also sets forth the claim of title, which the defendant asserts and avers is fraudulent and void as against the plaintiff.

Assuming all this to be true, the complaint presents a claim on which relief may be granted.

In a prior opinion the same court had held that a complaint did not state ground for equity relief and ordered it dismissed. ${ }^{47}$ On re-argument, the court found that opinion to be incorrect under the new rules of civil procedure because, under the fusion of law and equity, there was but one form of action and the court could render whatever relief, legal or equitable, was warranted by the facts. The court said: ${ }^{48}$

A remedy at law does not exclude one in equity, unless it is equally prompt and certain, and in other ways efficient, and where equity can give relief, plaimtiff ought not to be compelled to speculate on the chance of obtaining relief at law. See, American Life Insurance Co. v. Stewart, 300 U.S. 203, 204, 214, 57 S. Ct. 377, 81 L. Ed. 605, 111 A.L.R. 1268.

However, any discussion in the instant case as to whether he should be on the law side or the equity side of the court, would seem to be idle. Under Rule 2 of the Federal Rules of Civil Procedure, 28 U.S.C.A. following section 723c, there is but one form of action known as a "civil action." Substantive rules of law remain unchanged, and there is now but one procedure for their enforcement. The Federal statutes relating to actions brought on the wrong side of the court and to equitable defenses and equitable relief (See 397 and 398 of 28 U.S.C.A.), are superseded, as there is now only a "civil action" in which all relief must be obtained that could formerly have been secured at "law" or in "equity." If a party wants a jury trial and demands it pursuant to Rule 38, he must be accorded that right, if he was entitled to it at common law, or if it has been granted to him by Federal statute.

Our conclusion is that the defendant cannot set up the distinction between an action at law or in equity to defeat the jurisdiction of this court; and that we will now proceed with the case to determine what, if any, relief, the platintiff is entitled to.

if it sets forth facts which show that the plaintiff is entitled to any relief which the court can grant." (Emphasis added). Keiser v. Walsh, 118 F.2d 13, 14 (D.C.Cir. 1941). In the case just cited, the complaint had pleaded four alternative grounds for relief. The court of appeals, having found that as a claim was stated in the one in which it was alleged that the defendant, while in the plaintiff's employ, had persuaded another concern to cancel its contract of agency with the plaintiff, the complaint should not have been dismissed. Rule 54(c) of the Federal Rules of Civil Procedure specifically allows the granting of the relief to which a party is entitled, even if he has not asked for it in his pleadings. So these decisions comport with both the letter and the spirit of the rules.

47 Commonwealth Trust Co. v. Reconstruction F. Corp., 28 F.Supp. 645 (W.D. Pa. 1938).

48 Commonwealth Trust Co. v. Reconstruction F. Corp., 28 F.Supp. 586, 589-590 (D.C. Pa. 1939). (Emphasis added). 
This decision conforms to the principle that, in applying the rules, forn will be disregarded. As said in Sanderson v. Crowley: ${ }^{40}$

It is . . . unnecessary for us to decide whether this action is one that arose ex contractu or ex delicto, or whether it is partly in contract and partly in tort. ... An appellate court should not be too technical in respect to the pleadings in a case like this, which was fairly tried below upon the real issues between the parties, and where substantial justice has been done by the verdict and judgment under review. Under the Federal Rules of Civil Procedure, it is provided in Rule No. 1 that they shall be construed to secure the just, speedy, and inexpensive determination of every action. Rules 2 and 3 provide for only one form of action, to be known as a civil action, which shall be commenced by the filing of a complaint. Rule 18(a) provides that the plaintiff in his complaint inay join as many claims, either legal or equitable, as he may have against an opposing party. The appellees here have only two claims, which make up the judgment, one for the unused earnest money and the other for damages resulting from the tort committed by the appellants in inaking dehiveries under the contract.

And if it becomes important to determine whether the action is legal or equitable, in contract or in tort, the court will do so by considering the complaint as a whole, and will disregard inconsistent allegations. ${ }^{50}$ The courts also recognize, as did the early decision here discussed, that, despite the fusion, the distinction between law and equity still remains: ${ }^{51}$

They (the rules) have, for the purpose of achieving a simplified procedure, abolished technical differences, but cases that historically were equitable are still to be tried to the court, and those that were legal, to the jury.

\section{B. Simplicity of Pleading}

Rule 8, which restricts pleadings to a short and plain statement of (1) the grounds for the court's jurisdiction, (2) a similar statement of the clain showing that the pleader is entitled to relief and (3) a demand for judgment, has been applied quite frequently in bankruptcy. ${ }^{62}$ Even before the adoption of the rules, the General Orders in Bankruptcy prescribed simple forms in bankruptcy. ${ }^{53}$ In the rules, the courts have seen a new justification for not tying bankruptcy proceedings to rigid formulas. Thus, while holding that a petition for relief to file a proof of claim nunc pro tunc after confirmation of arrangnient for the settlement of unsecured debts, might be defective because of failure to allege fraud with particularity, ${ }^{64}$ the

49 180 F.2d 124, 127-128 (5th Cir. 1950).

50 National Discount Corp. v. O'Mell, 194 F.2d 452, 454-455 (6th Cir. 1952).

51 Bereslavsky v. Kloeb, 162 F.2d 862, 863 (6th Cir. 1947). And see Bereslavsky v. Caffey, 161 F.2d 499 (2d Cir. 1947).

52 FED. R. Civ. P. 8.

53 General Orders in Bankruptcx, Order 5.

54 Bankruptcy Act $\S 386,11$ U.S.C.A. \$ 786. 
United States Court of Appeals for the Second Circuit, nevertheless, ruled that the omission was not fatal. The court said: ${ }^{55}$

The petition at bar does not indeed allege the fraud with as much particularity as is desirable. But the omission is not fatal; it is only a pleading, and Rule $8(\mathrm{f}), 28$ U.S.C.A. following section 723c, demands that it "shall be so construed as to do substantial justice." Its general purport is plain enough, and if the debtor had really any doubt about its ineaning-which plainly it had not-it had, and still has, rehef under Rule 12(e); the day has passed when substantial interests stand or fall for such insubstantial reasons.

And where a trustee's complaint in a plenary suit to set aside the bankrupt's assignment of accounts receivable as a preferential transfer was attacked as insufficient, the court answered: ${ }^{56}$

Appellant contends that the bill of complaint should be stricken because it pleads conclusions rather than facts, or that appellee be ordered to make a more definite statement. We cannot agree with this contention. The new Federal Rules of Civil Procedure (Rule 8), 28 U.S.C.A. following section $723 \mathrm{c}$, prescribe a short and plain statement of the claim showing that the pleader is entitled to rehef. We are of opinion that the pleading complained of sufficiently comphed with the requirement of the rule and that it stated ultimate facts, not conclusions.

Even though an action to recover the value of property alleged to have been fraudulently transferred be insufficient as such, ${ }^{57}$ the jurisdiction of the court to entertain it under an alternative prayer to recover the sum as an unpaid stock subscription or a dividend paid out of capital will be sus-

55 Levenson v. B. \& M. Furniture Co., 120 F.2d 1009, 1010 (2d Cir. 1941). (Emphasis added). These decisions merely apply to bankruptcy the norms which courts, since the promultation of the rules, have applied to pleadings in all civil cases. See, for instance, Machado v. McGrath, 193 F.2d 706 (D.C. Cir. 1952) (action to declare plaintiff admissible to permanent residence and citizenship in the United States); United States v. Sinclair Refining Co., 126 F.2d 827, 830-831 (10th Cir. 1942) (recovery of damages for fraud from agent of Indians); Leimer v. State Mut. Life Assur. Co., 108 F.2d 302 (8th Cir. 1940) (claim to portion of proceeds of life insurance policy). The reason for these rulings is well summed up in Leimer v. State Mutual Assurance Co., supra at 306: "In view of the means which the Rules of Civil Procedure afford a defendant to obtain a speedy disposition of a claim which is without foundation or substance, by either securing a more definite statement or a bill of particulars under Rule $12(\mathrm{e})$ and thereafter applying for judgment on the pleadings under Rule $12(h)(1)$, or by moving for a summary judgment under Rule 56, we think there is no justification for dismissing a complaint for insufficiency of statement, except where it appears to a certainty that the plaintiff would be entitled to no relief under any state of facts which could be proved in support of the claim." (Emphasis added).

EB Hummel v. Wells Petroleum Co., 111 F.2d 883, 886 (7th Cir. 1940); this case is cited with approval by the Court of Appeals for the Ninth Circuit in Johnson v. Gardner, 179 F.2d 114, 117 (9th Cir. 1950).

E7 Bankruptcy Act §67d(2)(b), 11 U.S.C.A. § 107(d)(2)(b). 
tained. ${ }^{58}$ In this respect, the courts not only follow the spirit of the new rules, but their rulings accord with the aims of bankruptcy courts which are "equitable courts and seek to do equity." "50

\section{Joinder of Claims and Parties}

In California, we are used to broad rules of jomder of actions and causes. For they have been a part of our procedure for a long time. ${ }^{.00}$ They embody the broad rules of joinder, both as to claims and remedies and parties, which obtained in equity practice and in English practice and which have been adopted in many states. They aim to achieve the ideal of equity-that of settling in one controversy all the claims arising out of a matter as to all persons having an interest in it. ${ }^{61}$ The distinction which formerly obtained in equity between indispensable and proper parties is retained in providing for necessary and permissive joinder. All persons having a joint interest must be made parties and be joined on the same side. Community of interest is made the basis of obligatory joinder of parties. ${ }^{02}$ Permissive joinder is allowed, if the persons joined are interested in the relief sought, either jointly, severally or in the alternative, arising out of the transaction or occurrence, or if a question of law or fact common to all will arise in the action. Persons may be joined as defendants if there is a right of relief asserted against them jointly, severally, or in the alternative, arising out of the same transaction or occurrence, and if a question of law or fact common to all will arise.

Neither the plaintiff nor defendants need be interested in obtaining or resisting all the relief. Judgment may be given against one or more of the parties or defendants according to their respective rights or liabilities. If, by reason of such joinder, inconvenience might result, the court may order separate trials. ${ }^{63}$ The object of these sections is to allow the settlement, at one time, of as many controversies as may be existing between as many persons relating to one event or occurrence which gives rise to it.

58 Bankruptcy Act $\$ 23$, subd. b, 11 U.S.C.A. \$ 46(b) ; Schumacher v. Beeler, 293 U.S. 367 (1934); Green v. Gage, I86 F.2d 984 (5th Cir. 1951).

59 Continental Motor Corporation v. Morris, 169 F.2d 315, 317 (10th Cir. 1948).

60 Car. Code Crv. Proc. $\$ \S 378,379,379$ (a). See Yankwich, Joinder of Parties in the Light of Recent Statutory Changes, 2 So. CaIrF. L. Rev. 315 (1929).

01 FEd. R. Crv. P. 18.

62 FED. R. Crv. P. 19.

63 FED. R. CIv. P. 20. The distinction between proper and indispensable parties which Sections 19 and 20 embody was contained in old Equity Rule 39. See State of Washington v. United States, 87 F.2d 421, 427-428 (9th Cir. 1936). And so, where, under a "settlement agreement," in a controversy between holders of debentures of a corporation, the trustee, under the agreement, brought an action for specific performance against the parties to it, the court held that the members of the committee set up in the agreement to carry it into effect were necessary parties without whose presence the controversy could not be determined. Pioche Mmes Consol. v. Fidehity-Philadelphia Trust Co., 202 F.2d 944 (9th Cir. 1953).

Misjoinder is no longer a ground for dismissing the action. Parties may be dropped or added by the court on motion of the parties, or of its own initiative. A clain against a party may be severed and proceeded with separately, FED. R. Crv. P. 21. 
The social policy behind the rule of joinder has been stated by the reporter for the advisory committee: ${ }^{64}$

It is sound social policy that all items of potential irritation between parties be adjusted at one time, so that repose can be achieved and hitigation not continued interminably.

The policy which is behind the liberal rules of joinder has also found expression in recent rulings which allow referees in bankruptcy to render affirmative judgment on a counterclaim in favor of a trustee. Some of the cases, including one of my own, derive the power from the general nature of equity jurisdiction as applied in bankruptcy. ${ }^{65}$ Indeed, the case from the Fourth Circuit just cited derives the power chiefly from Section 68 (11 U.S.C.A. § 108) relating to "setoffs and counterclaims" by saying: ${ }^{68}$

There is naught in the text of the section which manifests an intention to subject the trustee to any restriction in the use of a setoff that would not have applied to the bankrupt if sued before his adjudication; and since in such an event the bankrupt could have had an affirmative judgment against his adversary under the ordinary rules of procedure, the trustee should be entitled to the same advantage in winding up the estate.

Other cases draw additional strength for their position from the federal rules relating to counterclaim, especially Rules 13 (a) and (b) and 41 (a) (2).$^{67}$ Whether the power is derived from one source or another, or both, its use in bankruptcy is salutary as it enables summary jurisdiction to be exercised in adjudicating by way of counterclaim, the claims of the estate against a claimant in the estate.

The federal courts have seen the wisdom of giving full scope to these objects in bankruptcy. Especially have they realized the beneficial provision of the rule ${ }^{68}$ which permits a suit to set aside a fraudulent conveyance to be maintained without first obtaining a money judgment. As to this phase of the rules of jomder, the Court of Appeals for the District of Columbia has said: ${ }^{68}$

Rule 18(b) is a substantial step toward the removal of obsolete and unnecessary impediments to the early and complete settlement of disputes.

64 Clark, The Proposed Federal Rules of Civil Procedure, 22 A.B.A.J. 447, 449 (1936).

65 Columbia Foundry Co. v. Lochner, 179 F.2d 630 (4th Cir. 1950); In re Mercury Engineering Co., 60 F. Supp. 786 (S.D. Cal. 1945). Bankruptcy Act $\S 23,11$ U.S.C.A. § 46; 11 U.S.C.A. § 108.

66 Columbia Foundry Co. v. Lochner, supra note 65 at 633.

67 See In re Solar Manufacturing Corp., 200 F.2d 327 (3d Cir. 1952); In re Nathan, 98 F. Supp. 686 (S.D. Cal. 1951) per Mathes, J. And see Gendel, Jurisdiction of a Referee in Bankruptcy to Render Affirmative Judgment on a Counterclain in Favor of a Trustee, 26 So. CALIF. L. REv. 167 (1953).

6S FED. R. Crv. P. 18(b).

69 Wynne v. Boone, 191 F.2d 220, 224 (D.C. Cir. 1951). 
... The Rule in abolishing any requirement of first securing judgment, necessarily strikes down any remaining vestige in the Federal courts of the old view that a creditor before bringing a suit to set aside a fraudulent conveyance should not only hold a judgment but should also issue execution on it and wait until the writ had been returned unsatisfied. It would appear obvious that a creditor who has reduced his claim to judgment should not be placed in a worse position or subjected to more onerous requirements than a creditor who has not obtained a judgment.

And when trial courts have exercised their discretion in allowing permissive joinder, subject to separate trials if inconvenience arose, their action has been sustained. As said by the Court of Appeals for the Second Circuit in a case in which certain claims only were determined at a time: ${ }^{70}$

Clearly a bankruptcy court must have some leeway to take up matters involving certain claimants only without the necessity of opening the whole case at large before it. In view of the size of the corporate structures involved in reorganization proceedings, often no other course would seem possible or certainly at least feasible. In civil actions the rules provide for the separate trial of separate issues "in furtherance of convenience or to avoid prejudice," Rule 42(b), and cf. Rules 13(i), 20(b) and 21, 28 U.S. C.A., following section $723 \mathrm{c}$. These rules certainly are applicable in bankruptcy imder G.O. 37, 11 U.S.C.A. following section 53, and, indeed, are perhaps more readily available there, since the practice of interlocutory appeals in bankruptcy provides for the complete splitting of the issues even upon review, whereas a civil appeal requires generally a final judgment disposing of an entire matter.

\section{Interpleader, Intervention and Class Actions}

The rules allow persons having claims against the plaintiff to be joined as defendants and be required to interplead when the claims are of such nature that the plaintiff may be exposed to double or multiple liability. Claims are not required to be of common origin. They may be adverse to and independent of one another, and the plaintiff may deny his liability in whole or in part to any or all the claimants. A defendant exposed to similar hability may obtain an interpleader by way of counter-claim or cross-claim. This allows both strict interpleader and bills in the nature of interpleader, and specifically exempts the special interpleader statute. ${ }^{71}$

Intervention is a creature of statute. It was carried into the equity rules froin the codes. ${ }^{72}$ The rules provide for intervention.

Intervention must be allowed when a statute of the United States confers an unconditional right, when the applicant's interest is inadequately

70 Elias v. Clarke, 143 F.2d 640, 644 (2d Cir. 1944). (Emphasis added).

T1 Fed. R. Crv. P. 22.

72 Old Equity Rule 38. See Equitable Trust Co.v. Connecticut Brass \& Mfg. Corp., 290 Fed. 712 (2d Cir. 1923). 
represented in the controversy and he may be bound by a judgment, or when he will be affected adversely by a distribution or other disposition of property which is in the custody of or subject to the control or disposition of the court or one of its officers. The section as it stands since its amendment in 1946 covers property (1) in actual custody of a court or officer, or (2) in the custody of another, but over which the court or one of its officers has control or the right of disposition. Intervention may be allowed (1) when a statute of the Urited States confers a conditional right to intervene, or (2) when the applicant's claim or defense and the main action have a question of law or fact in common. In allowing permissive intervention, the court must consider whether it will delay unduly or prejudice the adjudication of the rights of the original parties. It may decline to exercise its discretion if intervention would have either result. Officers and agencies of the government may intervene when a claim or defense in an action is based on a statute or on governmental action, order or regulation.

Intervention is made by motion served upon all the parties affected by it, which must state the grounds and be accompanied by a pleading setting forth the claim or the defense for which intervention is sought. ${ }^{73}$ As under the old equity rule and the codes, the intervenor must have a real interest in the controversy.

The rules make ample provision for class actions and defenses by a person on behalf of others with whom he has a common interest but who are too numerous to be brought before the court. The character of the right to be enforced may be (1) joint or common or secondary in the sense that the owner of a primary right refuses to enforce it, or (2) several and there is involved in the action the adjudication of claims affecting the several rights, and a common relief is sought. ${ }^{74}$ This form of action is well known to equity and the codes. ${ }^{75}$

The rule as to interpleader has a limited significance only im bankruptcy because the bankruptcy court, through its summary power to take possession of the property of the bankrupt, and to secure control over it, whether it is in the hands of the bankrupt or of others, can summon before it persons who claim an interest in it adversely to the bankrupt and adjudicate their claims, and bring in and substitute additional persons and parties when necessary for the complete determination of a matter in controversy. ${ }^{76} \mathrm{How}$ ever, the right to intervene has been recognized as of great importance. Thus, although no provision for intervention is made in proceedings under

73 FED. R. CIV. P. 24.

74 FEd. R. Crv. P. 23, (a) (2).

75 Old Equity Rule 37; Cac. Code Crv. Proc. $\$ 38$.

${ }^{76} \mathrm{Pt}$. II of this article; Bankruptcy Act $\S 2$ (a) (7), II U.S.C.A. $\$ 11(\mathrm{a})(7)$.

"At any stage of the bankruptcy proceeding, if the court finds itself in the legal custody of funds or property belonging to the stockholders of the bankrupt corporation, it has inherent 
Chapter X or XI of the Bankruptcy Act, the Supreme Court has held that the Securities and Exchange Commission could intervene in a Chapter X proceeding under Rule 24 , saying: ${ }^{77}$

This provision plainly dispenses with any requirement that the intervenor shall have a direct personal or pecuniary interest in the subject of the litigation. Cf. Pennsylvania v. Williams, supra. If, as we have said, it was the duty of the court to dismiss the Chapter XI proceeding because its maintenance there would defeat the public interest in having any scheme of reorganization of respondent subjected to the scrutiny of the Commission, we think it plain that the Commission has a sufficient interest in the maintenance of its statutory authority and the performance of its public duties to entitle it through intervention to prevent reorganizations, which should rightly be subjected to its scrutiny, from proceeding without it ....

The "claim or defense" of the Commission founded upon this interest has a question of law in common with the main proceeding in the course of which any party or a creditor could challenge the propriety of the court's proceedimg under Chapter XI. The claim or defense is thus within the requirement of Rule 24 and intervention was properly allowed.

The Court of Appeals for the Second Circuit has held that in an involuntary proceeding against a corporation a minority stockholder could be allowed to intervene. ${ }^{78}$ However, where a creditor had failed to oppose the confirmation of a sale, he could not imtervene on the petition for review after the expiration of time allowed for review. The court said: ${ }^{70}$

We do not think that it was the purpose of General Order 37 to substitute Rule 24(a) for the restrictive provisions of Sec. 39, sub.c; and the right to intervene "upon timely application", to be determined of course by the exercise of judicial discretion, does not supersede the statutory petition for review.

\section{E. Discovery Rules}

The federal rules have sought to minimize or eliminate altogether the element of surprise in a law suit by giving the widest scope to discovery in

power, after notice to all creditors of said stockholders and other interested parties, to adjudicate the rightful owners of, and the validity of all claims agamst, said property. The jurisdiction to do this is sole and exclusive; the proceeding is a classic one in rem; and no other court, not even a probate court in the state where the decedent resided, inay acquire subsequent to the time of bankruptcy a concurrent jurisdiction with reference to this same property witbout the consent of the bankruptcy court, the latter being a court where the creditors of the deceased busband may appear and be heard with reference to the widow's claim" Seiden v. Southland Chenilles, 195 F.2d 899, 904 (5th Cir. 1952).

Substitution of parties in case of death, incompetency, or transfer of interest is provided for generously under the rules. FED. R. Crv. P. 25. And the courts are tiberal in applying the rule. American Fidehty \& Cas. Co. v. All American Bus Lines, 190 F.2d 234, 236-237 (10th Cir. 1951).

77 Securities Comm'n v. U.S. Realty Co., 310 U.S. 434, 459-460 (1940).

78 Klein v. Nu-Way Shoe Co., 136 F.2d 986 (9th Cir. 1943).

79 In re Bender Body Co., 139 F.2d 128, 130 (6th Cir. 1943). 
advance of trial. This is done through the extensive use of depositions, ${ }^{80}$ through interrogatories and requests for admission, ${ }^{81}$ requests for production and inspection of documents, ${ }^{82}$ orders for physical and mental examination of persons, ${ }^{83}$ and admission of facts and of genuineness of documents. ${ }^{84}$ The object of the discovery procedure has been well stated by the Supreme Court in a leading case: ${ }^{85}$

The pre-trial deposition-discovery mechanism established by Rules 26 to 37 is one of the most significant innovations of the Federal Rules of Civil Procedure. Under the prior federal practice, the pre-trial functions of notice-giving, issue-formulation and fact-revelation were performed primarily and inadequately by the pleadings. Inquiry into the issues and the facts before trial was narrowly confined and was often cumbersome in method. The new rules, however, restrict the pleadings to the task of general notice-giving and invest the deposition-discovery process with a vital role in the preparation for trial. The various instruments of discovery now serve (1) as a device, along with the pre-trial hearing under Rule 16, to narrow and clarify the basic issues between the parties, and (2) as a device for ascertaining the facts, or information as to the existence or whereabouts of facts, relative to those issues. Thus civil trials in the federal courts no longer need be carried on in the dark. The way is now clear, consistent with. recognized privileges, for the parties to obtain the fullest possible knowledge of the issues and facts before trial.

When to the power of discovery inherent in bankruptcy through the right to examine the debtor ${ }^{86}$ and the right to resort to turnover proceedings or other methods to ascertain the right of the bankrupt in property ${ }^{87}$ is added the instrumentality of these discovery rules, the bankruptcy court is placed in a formidable position to ascertain facts relating to the estate of the bankrupt. The courts have taken advantage of the rules in order to assist the trustee in this respect. Thus, in a case from the Second Circuit in which the trustee sought to recover preferential payments by the bankrupt, the court granted a written request for admission by the claimant of the genuineness of certain of the documents upon which the trustee relied to establish his right to the property. Indeed, in this case the court held that

80 FED. R. Crv. P. 26-32. The equity rules relating to discovery, interrogatories, inspection and production of documents and the admission of execution and genuineness of instruments applied to bankruptcy proceedings by the terms of the Act. Bankruptcy Act $\$ 21(\mathrm{k}), 11$ U.S.C.A. $\$ 44(\mathrm{k})$. And the right to take depositions was also recognized. Bankruptcy Act \$21(b), 11 U.S.C.A. $\S 44($ b) .

81 FED. R. CIV. P. 33.

82 FED. R. CIV. P. 34.

83 FED. R. Crv. P. 35.

84 FED. R. Crv. P. 36.

85 Hickman v. Taylor, 329 U.S. 495, 500, 501 (1947).

86 Bankruptcy Act $\$ 21$ (a), 11 U.S.C.A. $\$ 44(a)$.

$87 \mathrm{Pt}$. II of this article. 
while the rule ${ }^{88}$ would seem to limit the admissions to documents, a liberal interpretation called for admissions as to any facts whether contained in documents or not. ${ }^{89}$ In the particular case, the claimants, executors of an estate, having failed to controvert the fact of insolvency, were held to be barred from questioning it. The court said: ${ }^{00}$

However, the opinion both of the courts and of commentators has been uniform that under Rule 36(a) a "matter of fact" not related to any document may be presented to the other party for admission or denial .... under the rule, therefore, the defendants cannot now controvert the fact of insolvency at the time of the payments.

\section{F. Pretrial Procedure}

A procedural scheme cannot achieve real effectiveness uuless it gives full opportunity to discover facts not available under ordinary legal procedure, and the court is allowed, through pretrial and summary procedure, to formulate or reduce issues and to eliminate unmeritorious claims. Lack of such mcidences accounts for much of the delay of which litigants complain.

The rules make ample provision for the attainment of these objects.

The court nay order the attorneys in an action to appear for a conference at which to consider simplifying the issues, amending the pleadings, securing admissions, limiting the number of expert witnesses, the advisability of a preliminary reference to a master, and other matters which nuay aid the disposition of the cause. The order made following the conference will govern the course of the subsequent trial. ${ }^{91}$ The court has the initiative under this rule. However, power is given to establish a pre-trial calendar on which the parties may place actions for pre-trial consideration.

Obligatory pre-trial calendars have been established in many federal courts in metropolitan areas. Even where they are not obligatory, pre-trial procedure may be used to advantage in bankruptcy.

\section{G. Summary Judgment}

Summary judgment culminates the provisions for disclosure in the rules. ${ }^{22}$ It lias conie to be recognized as an effective means of discovering lack of nierit, without time-consuming trial. It has been used in England

88 FED. R. Crv. P. 36(a).

80 Smyth v. Kaufman, 114 F.2d 40 (2d Cir.1940).

$80 \mathrm{Id}$. at 42 .

01 Rule 16. Pre-trial may be used effectively to clarify issues where complicated business transactions are involved in bankruptcy. See Shapiro v. Hoffman's Dairy Co., 105 F. Supp. 867 (ED. Mich. 1952). And see Yankwich, Chief Characteristics of Federal Trial Practice in Civil Cases, 12 F.R.D. 269, 278-283 (1952).

92 Fed. R. Crv. P. 56. 
for over fifty years. In Califorma, it was first confined to the municipal courts and later in 1933 extended to the superior courts. ${ }^{93}$

If the case is not fully adjudicated on the motion, the court, by order, may specify the issues remaining to be tried. Affidavits must be based on personal knowledge, and set forth facts admissible in evidence, by a person competent to testify to them. On cause shown, a party may be allowed to present facts by depositions or discovery. For presenting affidavits in bad faith, a party may be punished for contempt, and penalized with costs and attorney's fees.

Summary judgment will be granted if the Court is convinced "that the issue is not genuine, but feigned, and that there is in truth nothing to be tried." 94

Under the amendment of 1946 to this rule, the court may grant summary judgment on the question of liability, although a genuine issue remains as to the amount of damages.

Having had occasion recently to treat summary judgment very fully ${ }^{95}$ I will content myself with saying that summary judgment can be, and has been, used effectively in bankruptcy. Thus, the provision was used to dismiss an involuntary petition for reorganization where the court was satisfied that there was nothing to try and that the object of the petition was to harass the corporation. The court said: ${ }^{96}$

We do not therefore see any greater inconsistency between a trial and a motion for summary judgment in bankruptcy than in an ordinary action. No doubt, a judge must often come near to trying the issues before he can decide whether there are any issues to try, but that is inherent in the whole practice. Moreover, if the argument is good at all, it must also forbid motions to dismiss a petition for insufficiency in law upon its face, Rule 12(b) (6). That would certainly be an unwarranted interpretation ....

Nor is there anything peculiar to reorganizations under Chapter $\mathrm{X}$. True, it may be desirable to examine the debtor's affairs, and that will be impossible if the proceeding is suffocated at the outset. Furthermore, we recognize that involuntary reorganization is not a proceeding inter partes, once it is under way. Nevertheless, when the statute, $\S 131$, prescribed what facts a petition must allege, it did not mean that the petitioners should be entitled to interlocutory remedies under color of a sham petition. It is as unwarranted an invasion of the debtor's rights to subject it to inquisition upon

93 Cat. Code Crv. Proc. $\$ 437$ (c).

94 Curry v. MacKenzie, 239 N.Y. 267, 268, 146 N.E. 375,376 (1925).

${ }^{85}$ See Yankwich, Summary Judgment Under Federal Practice, 40 Carm. L. Rev. 204 (1952).

96 Cohen v. Eleven West 42nd St., Inc., 115 F.2d 531, 532 (2d Cir. 1940). Similarly, where, in a suit to set aside a fraudulent conveyance, the supporting documents and admissions showed that, as to certain named defendants, the purported transfer was fraudulent, summary judgment was properly entered. Beall v. Pinckney, 132 F.2d 924 (5th Cir. 1943). 
such a petition, as it is so to subject a defendant in an action. Rule 56 was intended to give an immediate relief for such wrongs, wherever practical.

However, where the pleadings raise an issuable fact as to whether a certain person received a preference, an order of the district court granting a summary judgment was reversed, the court saying: ${ }^{07}$

The presence of such an issue precludes summary judgment.

Similarly, where the trustee sought to set aside the transfer of property as a fraud on the creditors, a claim by a person of rights superior to those claimed under a mortgage presented a question which could not be disposed of by summary judgment. The court said: ${ }^{98}$

Our conclusion is that the plaintiff is entitled to an opportunity to prove, if he can, that he has some right, title, or interest in the personal property in suit and in whatever equity there may be in the real property over and above the liens of the existing mortgages upon it. That one reasonably may surmise that the plaintiff is unlikely to prevail upon a trial, is not a sufficient basis for refusing him his day in court with respect to issues which are not shown to be shain, frivolous, or so unsubstantial that it would obviously be futile to try them.

In this respect the courts have applied to summary judgments in bankruptcy the same rules which they have applied to other cases, namely, that, while use should be made of it in disposing of sham claims or defenses, it should not be resorted to to deprive a litigant of his right to have a genuine and real issue determined only upon a full trial. ${ }^{90}$

\section{H. Declaratory Judgment}

The rules preserve the benefits of the Declaratory Judgment Act, which declares that the district courts "in a case of actual controversy" may "declare the rights and other legal relations of any interested party." 100 The Declaratory Judgments Act is remedial in nature. Its aim was to introduce into federal procedure the benefit of the English rule which, in its present form, dates back to 1883 . It allowed declaration of rights whether any other relief was asked or not, in imitation of the equitable principles which lay at the foundation of the bills quia timet, and which sought to prevent wrongs or anticipated mischief and not merely to redress them when done. Through them, a party sought the aid of a court of equity because he feared some future probable injury to his rights or interests, and not because an injury had already occurred which required any com-

07 Landy v. Silverman, 189 F.2d 80, 82 (1st Cir. 1951).

88 Sprague v. Vogt, 150 F.2d 795, 801 (8th Cir. 1945).

${ }^{90}$ Sartor v. Arkansas Gas Corp., 321 U.S. 620, 627 (1944); Walling v. Fairmont Creamery Co., 139 F.2d 318 (8th Cir. 1943).

100 FED. R. Civ. P. 57. 
pensation or other relief. Given, therefore, an actual controversy, the aim of the Declaratory Judgments Act was to allow courts to take jurisdiction of it in order to grant declaratory relief either before or after "the stage of relief by coercion had been reached." ${ }^{101}$ As somebody once put it, the law is turned, through declaratory judgment, from a repair shop into a service station. Nonetheless, the Declaratory Judgments Act did not change the character of the judicial power of the federal courts or the essential requisites for its exercise. ${ }^{102}$ The tendency of courts has been to interpret the power granted by the Act "to declare rights and other legal relations" broadly, ${ }^{103}$ and to apply it to all justiciable controversies concerning rights and legal relations. ${ }^{104}$

The rule strengthens the Act by providing specifically that the existence of another adequate remedy shall not preclude the granting of the relief. It also allows the court to give precedence to actions for declaratory relief.

Declaratory judgment is not of great sigmificance in bankruptcy practice. This for the reason that the bankruptcy court has so many ways, through summary process, of determining rights. And, of course, the trustee, if he has any controversy with a person as to his rights to property, can always seek the advice of the bankruptcy court, or, if necessary, institute plenary proceedings to determine them.

Such plenary proceedings, whether instituted in a federal district court or in the state court, would be governed by the laws and rules of the court in which the action is instituted. ${ }^{105}$ In a matter of substantive rights, which arises under state laws, bankruptcy courts must follow the rules of the state. $^{108}$

\section{Evidence}

The civil rules do not establish a code of evidence. However, they declare that the rules of evidence shall be those recognized by statute or on the equity side of the court or the courts of general jurisdiction in the

101 Gully v. Interstate Natural Gas Co., 82 F.2d 145, 149 (5th Cir. 1936). See Donnely v. Mavar Shrimp \& Oyster Co., 190 F.2d 409, 410-411 (5th Cir. 1951).

102 Public Serv. Comm'n v. Wycoff Co., 344 U.S. 237, 241-244 (1952); Ashwander v. Valley Authority, 297 U.S. 288 (1936); United States v. West Virginia, 295 U.S. 463 (1935); Diggs v. Pennsylvania Utility Commission, 180 F.2d 623, 629 (3d Cir. 1950); Southern Pac. Co. v. McAdoo, 82 F.2d 121 (9th Cir. 1936).

103 Altvater v. Freeman, 319 U.S. 359, 363 (1943); Ashwander v. Valley Authority, 297 U.S. 288 (1936) ; Nashville C. \& St. L. Ry. v. Wallace, 288 U.S. 249, 261-264 (1933).

${ }^{104}$ Aetna Life Ins. Co. of Hartford, Conn. v. Martin, 108 F.2d 824 (8th Cir. 1940). The requirements for a justiciable controversy "are no less strict in a declaratory judgment proceeding than in any other type of suit." Federation of Labor v. McAdory, 325 U.S. 450, 461 (1945).

1054 COLIIER, BANkRUPTCY 390 (14th ed. 1940).

10028 U.S.C.A. $\$ 1652$. 
state in which the district court is held. Evidence is to be presented orally or in the most convenient manner, and rules favoring reception shall govern. ${ }^{107}$ The competency of witnesses is determined in the same manner. Great latitude of cross examination is allowed. One may call one's adversary or his agent, or the agent of a corporation or a partnership or association with the right to contradict him later. ${ }^{108}$ Offers of proof are allowed. In non-jury cases the excluded testimony may be transcribed. ${ }^{100}$ And motions may be heard on affidavits of parties or oral testimony and depositions. ${ }^{110}$ This is, indeed, a very broad rule which permits evidence to be received if it is admissible (a) under the statutes of the United States, (b) under equity rules, or (c) under the state law. Courts are, therefore, in a position to choose the tests which are most favorable. ${ }^{111}$ So far as the Court of Appeals for the Ninth Circuit is concerned, its present view is that the former equity.rule which presumed that improper evidence, even though received, was not acted upon is now the general rule. ${ }^{112} \mathrm{It}$ is quite evident that such an approach would command an even more liberal application in bankruptcy.

An interesting problem arose in one of my cases some years ago. ${ }^{113}$ One of the properties involved in a bankrupt estate was located in Nevada. As one of the questions before the referee was whether the interest of the bankrupt in a leased property had been properly forfeited by the landlord because of failure to properly farm the property, the referee was allowed to hold hearings in Nevada. In addition to hearing the testimony of witnesses, the referee viewed the premises. It was argued that the view of the premises by the referee was not evidence under the law of Nevada. I held that, under the mandate of the federal rules, ${ }^{114}$ the rules of evidence of California applied and giving effect to the California rules, under which a view of the premises is considered independent evidence upon which a finding could be based, I wrote: ${ }^{115}$

107 FED. R. CIV. P. 43(a).

108 Fed. R. CEv. P. 43(b).

109 FED. R. CIV. P. 43(c).

110 FED. R. CIV. P. 43(e).

111 Pfotzer v. Aqua Systems, 162 F.2d 779, 785 (2d Cir. 1947); Wright v. Wilson, 154 F.2d 616, 617 (3d Cir. 1946). The rule has ". . set the federal trend toward generous admissibility." Reck v. Pacific-Atlantic S.S. Co., 180 F.2d 866, 869 (2d Cir. 1950).

112 MacDonnell v. Capital Co., 130 F.2d 311, 318 (9th Cir. 1942). Prior to the enactment of the rules, the court followed the state rules of evidence in bankruptcy matters. So, in a plenary action by the trustee, the court held that, as the estate was administered in the State of Washington, the trustee was not bound by the testimony of one of his own witnesses, the bankrupt, because the law of evidence of the State of Washington did not make such testimony binding. A judgment against the trustee based upon the supposedly binding effect of such testimony was reversed. Sampsell v. Anches, 108 F.2d 945, 954 (9th Cir. 1940).

113 In re C. \& P. Co., 63 F. Supp. 400 (S.D. Cal. 1945).

114 FED. R. CIv. P. 43 (a).

115 In re C. \& P. Co., 63 F. Supp. 400, 408 (S.D. Cal. 1945). 
But the rules of evidence which govern hearings in bankruptcy court, are not those of Nevada. They are, under the Rules of Civil Procedure which apply to bankruptcy proceedings, those of the state where our court sits, the state of California. And the courts of California have held that whenever a trier of facts, be he judge or jury, views premises, such vieze is independent evidence upon which a finding can be based. So the conclusions of the Referee, based upon conflicting testimony and what he found when he was on the premises, are entitled to be sustamed unless clearly wrong.

\section{v}

\section{PROCESS AND AUXILIARY REMEDIES}

\section{Process}

The rules make the remedies of arrest, attachment, garnishment, replevin, sequestration or the like, allowed by the law of the state in which the trial is held, inure to the benefit of the litigants in district courts in the manner provided by state law. ${ }^{116}$ As this merely took the place of what was formerly provided in the statute, ${ }^{117}$ no special comment need be made.

One of the most helpful provisions in the new rules is the one which permits process to be served anywhere in the state in which the district court is located regardless of the number of federal districts into which the state may be divided. 118 The Supreme Court has held that this rule does not enlarge or diminish the venue or jurisdiction of the court but merely serves to implement the jurisdiction which the Congress has conferred by allowing the defendant to be brought into court at a place where the action is instituted. ${ }^{110}$

Although the jurisdiction of the bankruptcy court is confined to its "territorial limits", ancillary actions in aid of this jurisdiction may be brought in any district in which an interest claimed by the bankrupt's estate is located. ${ }^{120}$ The rule making process coextensive with the state's is very helpful in strengthening the power in ancillary proceedings. Very few business concerns in metropolitan areas in states which, like New York and California, have several districts, limit their activities to the particular district. A rule which allows persons residing outside the district, but within the state, to be reached by process, is very helpful in bankruptcy. Thus,

110 FEd. R. CIv. P. 64. The Bankruptcy Act gives the court power to order apprehension of the bankrupt. Bankruptcy Act $\$ 10$, 11 U.S.C.A. $\$ 28$ (1952). Procedure on execution to enforce a judgment by means of a writ of execution is made to conform to state procedure. FEd. R. Crv. P. 60. See Governor Clinton Co. v. Knott, 120 F.2d 149, 153 (2d Cir. 1941).

11728 U.S.C.A. former $\$ 726$.

118 FED. R. CT. P. 4(f).

110 Mississippi Pub. Co. v. Murphree, 326 U.S. 438, 445 (1946); Slocum v. Edwards, 168 F.2d 627, 631 (2d Cir. 1948).

120 Bankruptcy Act $\$ 2$ (a), 11 U.S.C.A. \$ 11(a); 8 C.J.S., BAnkruptcy $\$ 358$; Collett v. Adams, 249 U.S. 545, 547 (1919); Austrian v. Williams, 159 F.2d 67 (2d Cir. 1946) ; Montfort v. Korte, 100 F.2d 615, 617 (7th Cir. 1938); Noll v. Hodgson, 70 F.2d 19 (4th Cir. 1934). 
in a case which arose in the Southern District of New York, the referee, in exercising summary jurisdiction, caused service of process to be made on residents of the Western District of New York. The service being challenged, the Court of Appeals for the Second Circuit sustained it under Rule 4(f) of the Federal Rules of Civil Procedure, saying: ${ }^{121}$

The objection made by appellees that the Bankruptcy Act, $\S 2$, sub. a, 11 U.S.C.A., § 11, sub. a, vests only courts of bankruptcy with jurisdiction "within their respective territorial limits" is obviously not mconsistent, for, as we have just noted, this is a jurisdiction which is to be exercised within, and only within, the territorial limits of this particular bankruptcy court. Any other view would prove far too much and would imply that district courts, in their diversity or other jurisdiction, had power limited as to their every action to those parties who resided within the district limits.

\section{Injunction}

The Bankruptcy Court has extensive powers to ascertain the rights of the bankrupt to property held by others through examination of the bankrupt, ${ }^{122}$ and through turn-over proceedings and the summary means available. ${ }^{123}$ Incidental to the exercise of these powers, the bankruptcy court may make extensive use of the injunctive process to prevent interference by others with its jurisdiction through institution of prosecutions of actions in other courts or through other means. ${ }^{124}$ In addition to the general provisions establishing the jurisdiction of the courts in bankruptcy, ${ }^{125}$ the Bankruptcy Act contains special provisions for injunctive relief against actions pending elsewhere such as against a suit upon a claim from which a discharge would be a release. ${ }^{126}$ There is also the provision permitting it, in aid of the jurisdiction under Chapter $\mathrm{XI}$ of the Act, to enjoin or stay the commencement or continuation of suits other than suits to enforce liens without notice and, upon notice, to enjoin or stay even suits to enforce hens. ${ }^{127}$

Interesting questions have arisen as to the impact of the provisions on injunction in the rules upon these powers which preceded the rules. In substance, the rules carry into effect the statutory provisions which obtained before, ${ }^{128}$ and which forbade the issuance of preliminary injunction with-

121 Slocum v. Edwards, 168 F.2d 627, 631 (2d Cir. 1948) (Emphasis added).

122 Bankruptcy Act $\$ 21,11$ U.S.C.A. $\$ 44$.

123 See $\mathrm{Pt}$. II of this article.

124 Bankruptcy Act $\$ 2(a)(15), 11$ U.S.C.A. §15(a); Steelman v. All Continent Co., 301 U.S. 278 (1937) ; In re International Power Securities Corporation, 170 F.2d 399 (3d Cir. 1948); In re Sterling, 125 F.2d 104, 107 (9th Cir. 1942).

125 Bankruptcy Act $\$ 23,11$ U.S.C.A. § 46.

126 Bankruptcy Act $\$ 11$ (a), 11 U.S.C.A. $\$ 29$ (a).

127 Bankruptcy Act $\S 314,11$ U.S.C.A. $\$$ 714. See Meyer v. Rowen, 181 F.2d 715 (10th Cir. 1950).

12328 U.S.C.A. old §§ 381, 382, 383. 
out notice, but which provided for a temporary restraining order for a period not to exceed ten days, and security for issuing an injunction with the added requirement that the order contain the reasons for its issuance and be specific in the things sought to be done or restrained. ${ }^{129}$ The ten day limit for a temporary restraining order has been held binding on the bankruptcy court. ${ }^{130}$ So has the requirement of security. ${ }^{131}$

Where the injunctive process is used to protect the estate in bankruptcy court $^{132}$ the requirements of the rule do not apply. This has been applied to the requirement as to security. ${ }^{133}$

It would seent that the courts hesitate to trammel the bankruptcy court as to matters in which it may take summary action. However, when it conies to plenary actions, they feel that the trustee should be treated like any other litigant and be subject to the restrictions of the rule against injunctions.

The Court of Appeals for the Second Circuit lias stated the basis for this ruling in this simple language: ${ }^{134}$

This being a plenary action, summary jurisdiction does not attach, and a temporary restraining order should not issue without compliance with rule 65(c). To us, the rule seems plain, definite and unmistakable. There is nothing ambiguous about it.

While the courts of bankruptcy are statutory courts, the exercise of their powers-especially of those to bring into the estate the property of the bankrupt, are administered in accordance with the general principles and accepted practices in equity. ${ }^{135}$

Plenary actions, lowever, partake more of the character of ordinary actions at law, and the rules and legal principles applicable to such actions will be enforced, even to the extent of allowing trial by jury. ${ }^{136}$

129 FED. R. Crv. P. 65.

130 Benitez v. Anciani, 127 F.2d 121 (1st Cir. 1942).

131 11 U.S.C.A. $\$ 65$ (c); see, Chatz v. Freeman, 204 F.2d 764, 768 (7th Cir. 1953).

132 Steelman v. All Continent Co., 301 U.S. 278 (1937).

133 Magidson v. Duggan, 180 F.2d 473, 479 (8th Cir. 1950); Doyne v. Saettele, 112 F.2d 155, 162 (8th Cir. 1940).

134 Chatz v. Freeman, 204 F.2d 764, 768 (7th Cir. 1953). This case and the cases in the preceding note would seem to cast doubt on the soundness of the ruling in Benitez v. Anciani, 127 F.2d 121 (1st Cir. 1942), where the limitation was applied to an injunction issued by the bankruptcy court in the exercise of its general bankruptcy powers. On the whole subject, see Rcich, Injunctive Relief Under the Bankruptcy Act, 19 BrookLYN L. Rev. 222 (1953).

135 Bankruptcy Act $\S \S 2$ (a) (15), 70, 11 U.S.C.A. \$ $\$ 11$ (a) (15), 110. Columbia Gas Co. v. Amer. Fuel Co., 322 U.S. 379, 383 (1944); Securities Comm'n v. U.S. Realty Co., 310 U.S. 434, 455-456 (1940); In re Lustron Corp., 184 F.2d 789, 794-795 (7th Cir. 1950).

136 Duda v. Sterling Mfg. Co., 178 F.2d 428, 435 (8th Cir. 1949). A jury trial on the question of insolvency may be asked by the bankrupt in an involuntary proceeding. Bankruptcy Act $\S 19,11$ U.S.C.A. $\$ 43$; see Johnson v. Garnder, 179 F.2d 114, 116 (9th Cir. 1949). When this is done, the right of the court to render a judgment notwithstanding the verdict of the jury, under FED. R. Crv. P. 50(b), is given recogmition. Upholding the action of the trial 


\section{CONCLUSION}

The preceding discussion shows that the significant incidences of the procedure contained in the Federal Rules of Civil Procedure have been fruitful in beneficial results when applied to bankruptcy. Because the principles applicable to equity practice have obtained in bankruptcy, some of the provisions of the rules which either embody general equity practice or which were actually taken from the former equity rules, were applied in bankruptcy even before the new civil rules were promulgated. But it is quite evident that the application of the rules has strengthened bankruptcy procedure in the exercise of those broad powers which the bankruptcy courts already possessed and has added new tools for their exercise. And the reason is obvious.

The object of the new rules is to secure the just, speedy and inexpensive determination of actions. ${ }^{137}$ This is desirable in any procedural scheme. For the ultimate aim of all legal proceedings is to do justice between the parties. ${ }^{138}$ Quick and inexpensive procedure is a means for achieving this end. The chief purpose of the bankruptcy law is the discharge of the debtor through the equal distribution of his estate. ${ }^{139}$ Both are matters of public

judge who had set aside the verdict of the jury in favor of the defendants, in an involuntary proceeding, and substituted for it a judgment adjudicating the defendants to be bankrupt, the Court of Appeals for the Fifth Circuit said:

"The right to a trial by jury given by the bankruptcy act differs from the trial of an issue of fact in chancery; the former is absolute, and cannot be withheld in the discretion of the court. A verdict of the jury in a bankruptcy case has the same effect as the verdict of a jury in an action at law in the federal court.

"Rule 50 (b) of said rules of civil procedure is not in conflict with the bankruptcy act or said general orders, since it adds nothing of substance to the rights of litigants, but merely renders unnecessary a formal reservation of the question of law and regulates the time and manner of moving for judgment on the ground of the court's refusal to direct a verdict." Newton v. Glenn, 149 F.2d 879, 880-881 (5th Cir. 1945).

This view conforms to the principle declared by the Supreme Court that the rules "... prescribe the methods by which the jurisdiction of the federal courts is to be exercised but do not enlarge the jurisdiction." United States v. Sherwood, 312 U.S. 584, 591 (1941). The courts have also apphed to bankruptcy the limitation imposed by the rules upon the time for filing a notion for a new trial. FED. R. Crv. P. 59(b); see In re Brigantine Beach Hotel Corp., 197 F.2d 296, 300 (3d Cir. 1952).

137 FED. R. CIV. P. 1.

138 N.Y. Central R.R. Co. v. Johnson, 279 U.S. 310, 318 (1929). "Rules of practice and procedure are devised to promote the ends of justice, not to defeat them." (Emphasis added).

Hormel v. Helvering, 312 U.S. 552, 557 (1941).

139 "The determination of the status of the honest and unfortunate debtor by his liberation from encumbrance on future exertion is matter of public concern. . . " Hanover National Bank v. Moyses, 186 U.S. 181, 192 (1902).

"The purpose of the Bankruptcy Law, passed pursuant to the power of Congress to establish a uniform system of bankruptcy throughout the United States, is to place the property of the bankrupt, wherever found, under the control of the court, for equal distribution among the creditors." Straton v. New, 283 U.S. 318, 320-321 (1931).

"The discharge of the debtor bas come to be an object of no less concern than the distribution of his property." Louisville Bank v. Radford, 295 U.S. 555, 588 (1935). 
concern. Speed and economy of administration are laudable methods for obtaining this result. These, of course, are to be equated with the equitable character of the courts which admimister bankruptcy. ${ }^{140}$ So the identity of aims between the Federal Rules of Civil Procedure and the norms of bankruptcy should make the rules, in the future, as they have been in the past, a valuable instrumentality im bankruptcy. 